
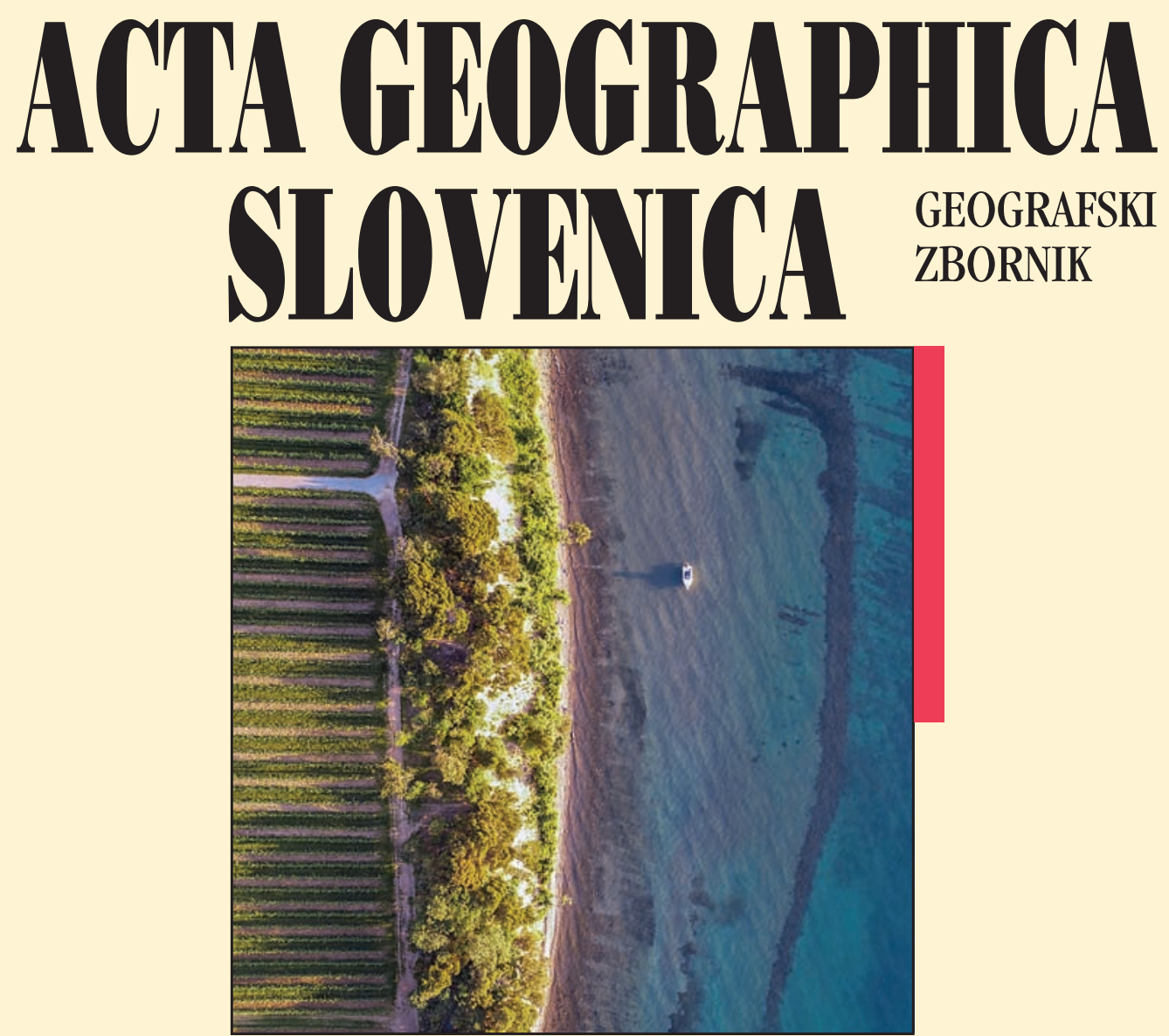


\section{ACTA GEOGRAPHICA SLOVENICA GEOGRAFSKI ZBORNIK 60-1 - 2020}

\section{Contents}

Mojca POKLAR

Comparison of the sonar recording method and the aerial photography method

for mapping seagrass meadows

Vanja PAVLUKOVIĆ, Uglješa STANKOV, Daniela ARSENOVIĆ

Social impacts of music festivals: A comparative study of Sziget (Hungary) and Exit (Serbia)

Péter János KISS, Csaba TÖLGYESI, Imola BÓNI, László ERDÖS, András VOJTKÓ, István Elek MAÁK, Zoltán BÁTORI

The effects of intensive logging on the capacity of karst dolines to provide potential microrefugia for cool-adapted plants

Radu SĂGEATĂ

Commercial services and urban space reconversion in Romania (1990-2017)

Kristina IVANČIČ, Jernej JEŽ, Blaž MILANIČ, Špela KUMELJ, Andrej ŠMUC Application of a mass movement susceptibility model in the heterogeneous Miocene clastic successions of the Slovenj Gradec Basin, northeast Slovenia

Andrej GOSAR

Measurements of tectonic micro-displacements within the Idrija fault zone in the Učja valley (W Slovenia)

Piotr RAŹNIAK, Sławomir DOROCKI, Anna WINIARCZYK-RAŹNIAK

Economic resilience of the command and control function of cities in Central and Eastern Europe

Mateja FERK, Rok CIGLIČ, Blaž KOMAC, Dénes LÓCZY

Management of small retention ponds and their impact on flood hazard prevention in the Slovenske Gorice Hills

\section{Gregor KOVAČIČ}

Sediment production in flysch badlands: A case study from Slovenian Istria

Vesna LUKIĆ, Aleksandar TOMAŠEVIĆ

Immigrant integration regimes in Europe: Incorporating the Western Balkan countries

Mitja DURNIK

Community development: Local Immigration Partnerships in Canada and implications for Slovenia

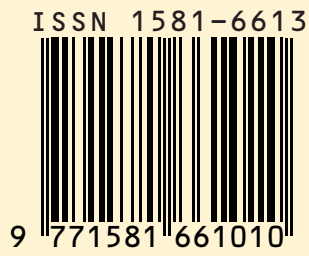




\section{THE EFFECTS OF INTENSIVE LOGGING ON THE CAPACITY OF KARST DOLINES TO PROVIDE POTENTIAL MICROREFUGIA FOR COOL-ADAPTED PLANTS}

Péter János Kiss, Csaba Tölgyesi, Imola Bóni, László Erdős, András Vojtkó, István Elek Maák, Zoltán Bátori

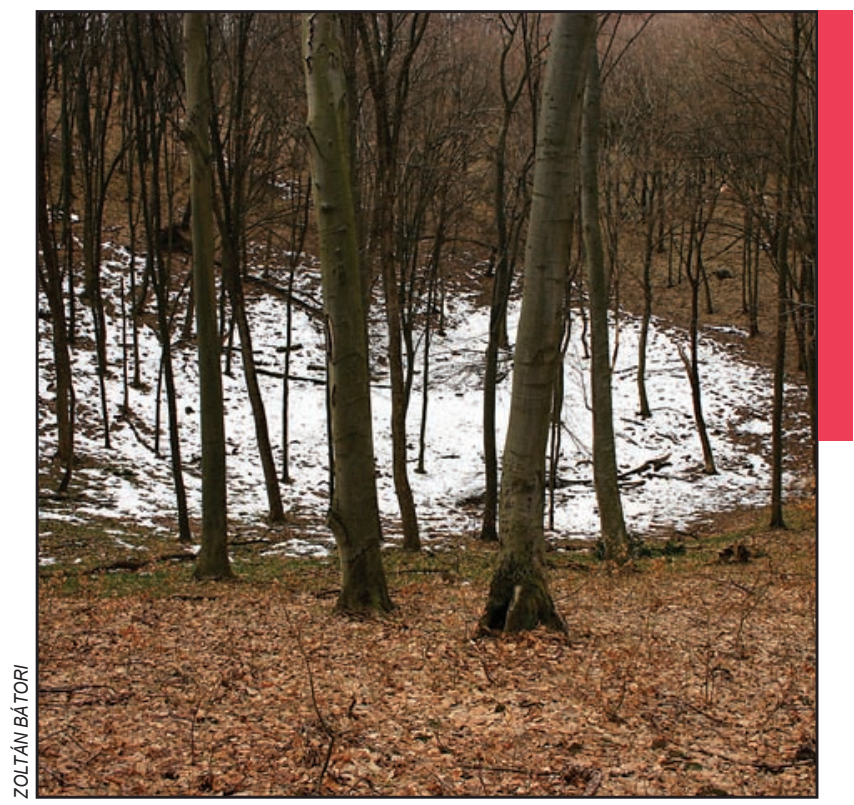

Snow cover in the bottom of a large doline in the Mecsek Mountains, in the spring of 2018 (11 $1^{\text {th }}$ March, 2018). 
DOI: https://doi.org/10.3986/AGS.6817

UDC: $911.2: 581.9(439)$

581.9:551.448(439)

COBISS: 1.01

Péter János Kiss ${ }^{1}$, Csaba Tölgyesi² ${ }^{2}$ Imola Bóni ${ }^{2}$, László Erdős ${ }^{3}$, András Vojtkó ${ }^{4}$, István Elek Maák ${ }^{5}$, Zoltán Bátori $^{2}$

\title{
The effects of intensive logging on the capacity of karst dolines to provide potential microrefugia for cool-adapted plants
}

\begin{abstract}
Dolines are local depressions of karst surfaces. They can be considered potential microrefugia for various species. We investigated the plant species composition and vegetation pattern of two medium-sized dolines in Hungary before and 10 years after logging, and analysed how different species groups (oak forest species, beech and ravine forest species and disturbance-tolerant species) were affected. The cover and number of oak forest species and disturbance-tolerant species increased, while the cover and number of beech and ravine forest species decreased within dolines due to logging. Therefore, their species composition and vegetation pattern have changed substantially, and dolines have partially lost their capacity to act as safe havens for plant species adapted to cooler conditions.
\end{abstract}

KEY WORDS: biology, geography, climate change, logging, cool-adapted plants, karst area, vegetation pattern, Hungary

\section{Vpliv intenzivne sečnje na sposobnost kraških vrtač za zagotavljanje potencialnih mikrozatočišč za hladnoljubne rastline}

POVZETEK: Vrtače so kraške kotanje na kraškem površju, ki lahko zagotavljajo mikrozatočišča različnim vrstam. Preučili smo vrstno sestavo in razporeditev vegetacije v dveh srednje velikih vrtačah na Madžarskem pred sečnjo gozda in deset let po njej ter analizirali vpliv sečnje na različne skupine rastlinskih vrst (vrste v hrastovih gozdovih, vrste $\mathrm{v}$ bukovih gozdovih in vrste v gozdovih plemenitih listavcev ter vrste, ki so odporne na različne motnje). Pokrovnost in število vrst $v$ hrastovih gozdovih ter vrst, odpornih na motnje se je povečalo, pokrovnost in število vrst $\mathrm{v}$ bukovih gozdovih ter v gozdovih plemenitih listavcev pa se je zaradi sečnje lesa v vrtačah zmanjšalo. Zato sta se močno spremenili vrstna sestava in razporeditev vegetacije v teh gozdovih, vrtače pa so delno izgubile funkcijo varnih zatočišč za hladnoljubne rastlinske vrste.

KLJUČNE BESEDE: biologija, geografija, podnebne spremembe, sečnja, hladnoljubne rastline, kraški svet, razporeditev vegetacije, Madžarska

The paper was submitted for publication on June $24^{\text {th }}, 2018$.

Uredništvo je prejelo prispevek 24. junija 2018.

\footnotetext{
${ }^{1}$ University of Szeged, Department of Ecology, Doctoral School of Environmental Sciences, Szeged, Hungary kisspeterjanos003@gmail.com

${ }^{2}$ University of Szeged, Department of Ecology, Szeged, Hungary

festuca7@yahoo.com,imolaboni@gmail.com, zbatory@gmail.com

${ }^{3}$ MTA Centre for Ecological Research, Department of Terrestrial Ecology, Vácrátót, Hungary erdos.laszlo@okologia.mta.hu

${ }^{4}$ Eszterházy Károly University of Applied Sciences, Department of Botany, Eger, Hungary vojtkoa@gmail.com

${ }^{5}$ University of Szeged, Department of Ecology, Szeged, Hungary, and Polish Academy of Sciences, Museum and Institute of Zoology, Warsaw, Poland

bikmakk@gmail.com
} 


\section{Introduction}

Stable habitats buffered from climate changes are known as refugia (Ashcroft 2010; Keppel et al. 2012). Microrefugia are small sites with locally favourable environmental conditions (e.g., microclimate and soil moisture) amidst unfavourable regional environments (Rull 2009; Gentili et al. 2015). Therefore, they facilitate the in situ persistence of species. Convergent environments (e.g., basins, ravines and valleys) may act as microrefugia (Dobrowski 2010; Bátori et al. 2014a), since their topographic complexity provides a diversity of microclimates (Whiteman et al. 2004), allowing species to track suitable conditions with minimal movement. In Europe, dolines (local depressions of karst surfaces) may also constitute microrefugia (Bátori et al. 2009), as cold-air pooling occurs within them and north-facing slopes receive less insolation than surrounding areas (Bárány-Kevei 1999). For instance, dolines in Central and Southeastern Europe are known to maintain relict populations of boreal and high-mountain plant species (Ritter Beck von Mannagetta 1906; Horvat 1953; Kobal et al. 2015). Therefore, they have the capacity to harbour many plant and animal taxa that are rare or absent in the surrounding areas (Modrić Surina and Surina 2010; Kemencei et al. 2014; Raschmanová et al. 2015; Růžička et al. 2016; Bátori et al. 2019a). This capacity depends on small- and large-scale environmental factors (Keppel et al. 2015), such as macroclimate, depth/diameter ratio, slope aspect and vegetation cover (Bátori et al. 2012; 2017). Although dolines act as key habitats for various taxa, the effects of human activity on their species-holding capacity have rarely been assessed and raise further questions.

Expansive economic growth and urbanization pose a serious threat to karst landforms (Breg Valjavec, Zorn and Čarni 2018; Bátori et al. 2019b). For instance, many dolines have been filled up with construction waste and rock debris in Slovenia during the expansion of settlements and highway constructions (Breg 2007; Kovačič and Ravbar 2013). Consequently, the shape and depth of these dolines have changed markedly (Cernatič-Gregorič and Zega 2010; Breg Valjavec 2014; Breg Valjavec, Ribeiro and Čarni 2017) and many of them have lost their capacity to act as safe havens for biodiversity in changing climate. In Crete, road construction, overgrazing and nutrient addition by sheep are the main threats to the endemic plant species of dolines (Egli 1991; Iatroú and Fournaraki 2006). Human-induced changes in forest cover also have the potential to negatively influence the species diversity of karst depressions (Bárány-Kevei 2011).

Deforestation is a serious threat to the biological diversity of karst surfaces (Calò and Parise 2006). Species respond to changes in light, nutrient, soil moisture and temperature individualistically (Stewart 2010), however, when changes are strong and fast, functionally similar species may respond similarly (Birks and Ammann 2000). Microhabitat changes induced by logging are especially pronounced in dolines (Lehmann 1970), where environmental conditions vary considerably from slope to slope and from top to bottom (Whiteman et al. 2004; Bátori et al. 2011). Previous studies revealed that the diurnal fluctuations in temperature, humidity and wind speed are less extreme in forested dolines than in non-forested ones (Lehmann 1970). To better understand the impact of logging on the species-holding capacity of karst dolines, we need to document the changes in species composition and vegetation pattern over time.

The western part of the Mecsek Mountains (Hungary) has typical karst landform features, such as dolines, with funnel-shaped geometry and unique microclimate (Bátori et al. 2011). Our previous studies showed that larger dolines have the capacity to enable the persistence of cool-adapted plant species and diverse forest types that are absent from the surrounding plateau (Bátori et al. 2012; 2014a; 2014b; 2017). Intensive logging began about 10 years ago in this region, and mature forest cover has been reduced to approximately 30-40 percent of its original extent in some dolines. In the present study, we investigated the changes in the species-holding capacity of karst dolines induced by logging. Specifically, we studied the plant species composition and vegetation pattern in two dolines in the Mecsek Mountains before and after logging, and compared the focal species groups to each other.

\section{Methods}

\subsection{Study area}

The study area is a limestone karst landscape of about $30 \mathrm{~km}^{2}$ in the western part of the Mecsek Mountains (Figure 1), located at an altitude between $250-500 \mathrm{~m}$. The climate is continental with sub-Mediterranean influences: moderately warm (mean annual temperature is $9.5^{\circ} \mathrm{C}$ ) and moderately humid (mean annual 
precipitation is $740 \mathrm{~mm}$ ) (Dövényi 2010). The number of dolines is about 2200 (Hoyk 1999). Beech and oak-hornbeam forests cover the slopes of dolines and the major part of the plateaus between dolines, while ravine forests cover the bottom of larger dolines (Bátori et al. 2012).

\subsection{Vegetation resurvey}

Two medium-sized dolines were selected (doline 1: WGS 46.13359 N, 18.16589 E; doline 2: WGS $46.13131 \mathrm{~N}$, 18.17164 E) with a funnel-shaped geometry. Dolines were about $70 \mathrm{~m}$ in diameter and about $14 \mathrm{~m}$ deep. Both dolines were sampled before logging (about 110 years old forests, in 2007) and 10 years after logging (in 2017), using the same method. The cover of mature trees within dolines has been reduced to approximately 30-40 percent of its original extent (Figure 1). Because the greatest differences in species composition were expected between the north- and south-facing slopes (Bátori et al. 2012), we established a transect with north-to-south orientation across the dolines, traversing the deepest points. Transects began and ended on doline rims. Each transect consisted of $1 \mathrm{~m} \times 1 \mathrm{~m}$ plots spaced at 2 -m intervals. We recorded the cover of all herbs, shrubs and tree saplings in all plots. A total of 114 plots were surveyed. Nomenclature follows The Plant List (2018).

\subsection{Species grouping}

We classified all plant species according to their habitat preference (Horváth et al. 1995). Three larger functional groups (cf. Troiani et al. 2016) were established:

- »oak forest species« (i.e. typical species of turkey oak-sessile oak forests and drier oak-hornbeam forests),

- »beech and ravine forest species« and

- »disturbance-tolerant species« (i.e. ruderals).

All three functional groups were analysed using both the cover and presence/absence data of species. Since beech and ravine forest species are the best indicators of cool microhabitats in our study area, this functional group was considered to be particularly relevant to detect changes in the species-holding capacity of dolines.

\subsection{Data analyses}

We used permutational multivariate analysis of variance (PERMANOVA) to test the effect of logging on plant assemblages. We used the raw cover data of species for each sampling plot in the source matrices. We applied the Bray-Curtis index, and performed 5,000 permutations. PERMANOVAs were calculated in R statistical environment (R Core Team 2018) using the adonis function of the »vegan « package (Oksanen et al. 2018). We prepared non-metric multidimensional scaling (NMDS) ordinations (cover values and Bray-Curtis index) to visually illustrate differences in vegetation pattern.

The diagnostic species of the dolines before and after logging were determined by calculating the phi $(\Phi)$ coefficient of association between species and habitat (Chytrý et al. 2002). Species with $\Phi>0.1$ were considered diagnostic. Non-diagnostic species were excluded with Fisher's exact test $(p<0.05)$. Calculations were done with the JUICE 7.0.25 program (Tichý 2002).

We used linear mixed-effect models (LMMs) with Gaussian error term for the comparison of the cover of functional groups, and generalized linear mixed-effects models (GLMMs) with Poisson error term for the comparison of the species numbers of functional groups. All analyses were carried out in R (R Core Team 2018). In the models, the management types (unlogged and logged) were included as fixed factors, the cover and number of species as dependent variables, and the location (i.e. doline 1 and 2) as random factor. LMMs were performed using the lme function from the "nlme " package (Pinheiro et al. 2018), while GLMMs were performed using the glmer function from the »lme4 « package (Bates, Maechler and Bolker 2013). 
Acta geographica Slovenica, 60-1, 2020
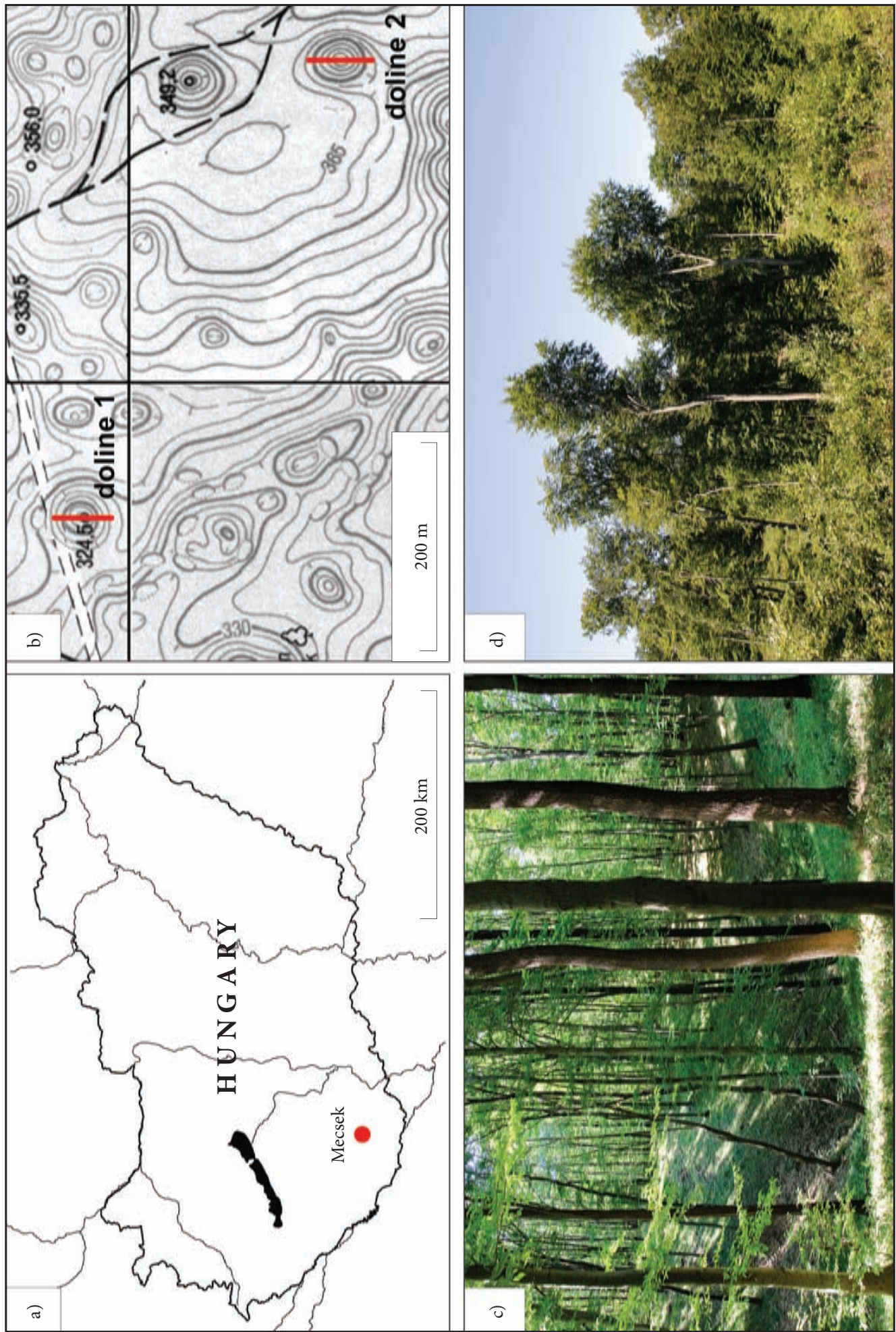


\section{Results}

A total of 72 vascular plant species were recorded in the plots. Five diagnostic species (one oak forest species and four beech and ravine forest species) were identified before logging and 15 (six oak forest species, three beech and ravine forest species, and six disturbance-tolerant species) after logging (Table 1). NMDS ordinations (stress factor: 0.24 and 0.22 , respectively) showed that the compositional pattern of the vegetation changed significantly (PERMANOVA: $\mathrm{F}=6.8$ and 7.8 , respectively, $p<0.001$ ) after logging (Figure 2).

The cover and number of oak forest species (e.g., common bugle (Ajuga reptans), fragrant hellebore (Helleborus odorus) and butcher's broom (Ruscus aculeatus)) and disturbance-tolerant species (e.g., deadly nightshade (Atropa belladonna), American burnweed (Erechtites hieracifolia) and Japanese hedgeparsley (Torilis japonica)) were higher after logging ( $p<0.001$ and $p<0.05$, respectively), while the cover and number of beech and ravine forest species (e.g., enchanter's nightshade (Circaea lutetiana), common lungwort (Pulmonaria officinalis) and spineless butcher's broom (Ruscus hypoglossum)) were higher before logging $(p<0.001$ and $p=0.06$, respectively) (Figure 3 ).

\section{Discussion}

Karst depressions provide suitable microhabitats for a variety of species, but human-activity may influence their species-holding capacity. To our knowledge, this is the first study to report evidence of a decrease in species-holding capacity within forested dolines confirmed with repeated sampling. We have shown that 10 years after logging (30-40 percent of the original forests remained intact) the vegetation pattern and species composition changed substantially within dolines, and they have partially lost their capacity to act as safe havens for a number of plant species adapted to cooler conditions.

As previous studies have shown, cool and humid dolines in Eurasia have the capacity to support animal and plant populations outside their main distribution ranges (Raschmanová et al. 2015; Bátori et al. 2017; Su et al. 2017), and microclimate is a significant predictor of the species diversity within them (Rủžička et al. 2016). Although microclimatic differences between the slopes of forested dolines are less pronounced

Table 1: Diagnostic species of the dolines before and after logging $(p<0.05)$. Species are listed by decreasing values of the phi $(\Phi)$ coefficient of association between species and habitat. Letters in parenthesis indicate functional groups: (a) oak forest species, (b) beech and ravine forest species and (c) disturbance-tolerant species.

\begin{tabular}{ll}
\hline Before logging & \\
\hline Ivy - Hedera helix (a) & 0.47 \\
Yellow archangel - Lamium galeobdolon s.l. (b) & 0.37 \\
Wood speedwell - Veronica montana (b) & 0.33 \\
Woodruff - Galium odoratum (b) & 0.28 \\
Dog's mercury - Mercurialis perennis (b) & 0.28 \\
\hline After logging & \\
Hairy blackberry - Rubus hirtus agg. (c) & 0.42 \\
Stinging nettle - Urtica dioica (c) & 0.42 \\
European hornbeam - Carpinus betulus (b) & 0.35 \\
Wood small-reed - Calamagrostis epigejos (c) & 0.34 \\
Wood sedge - Carex sylvatica (b) & 0.27 \\
Annual fleabane - Stenactis annua (c) & 0.24 \\
Hairy St Johns-wort - Hypericum hirsutum (c) & 0.23 \\
Turkey oak - Quercus cerris (a) & 0.23 \\
Lady fern - Athyrium filix-femina (b) & 0.21 \\
Wall lettuce - Lactuca muralis (a) & 0.21 \\
Goat willow - Salix caprea (c) & 0.21 \\
Silver linden - Tilia tomentosa (a) & 0.21 \\
Germander speedwell - Veronica chamaedrys (a) & 0.21 \\
Wood melick - Melica unifflora (a) & 0.20 \\
Sessile oak - Quercus petraea (a) & 0.19 \\
\hline
\end{tabular}


a)

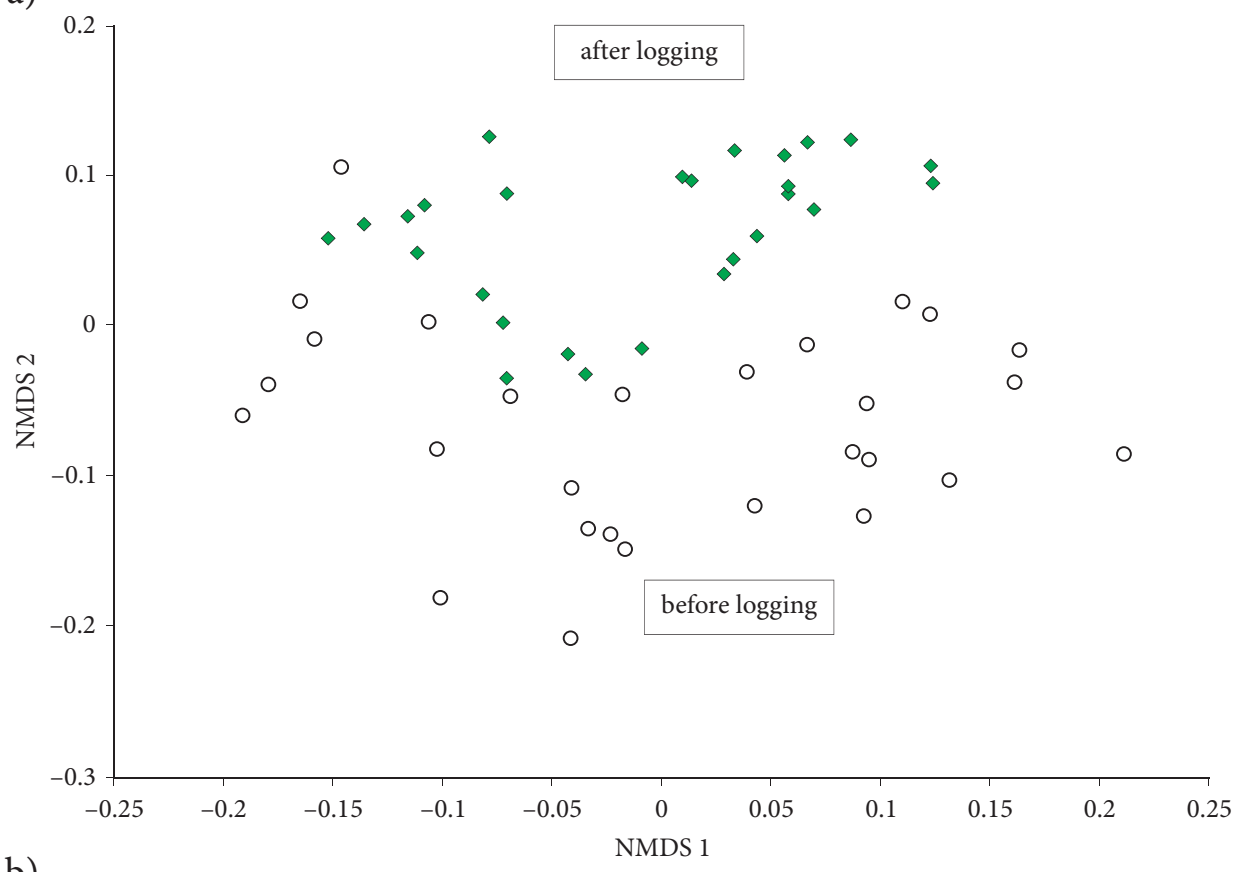

b)

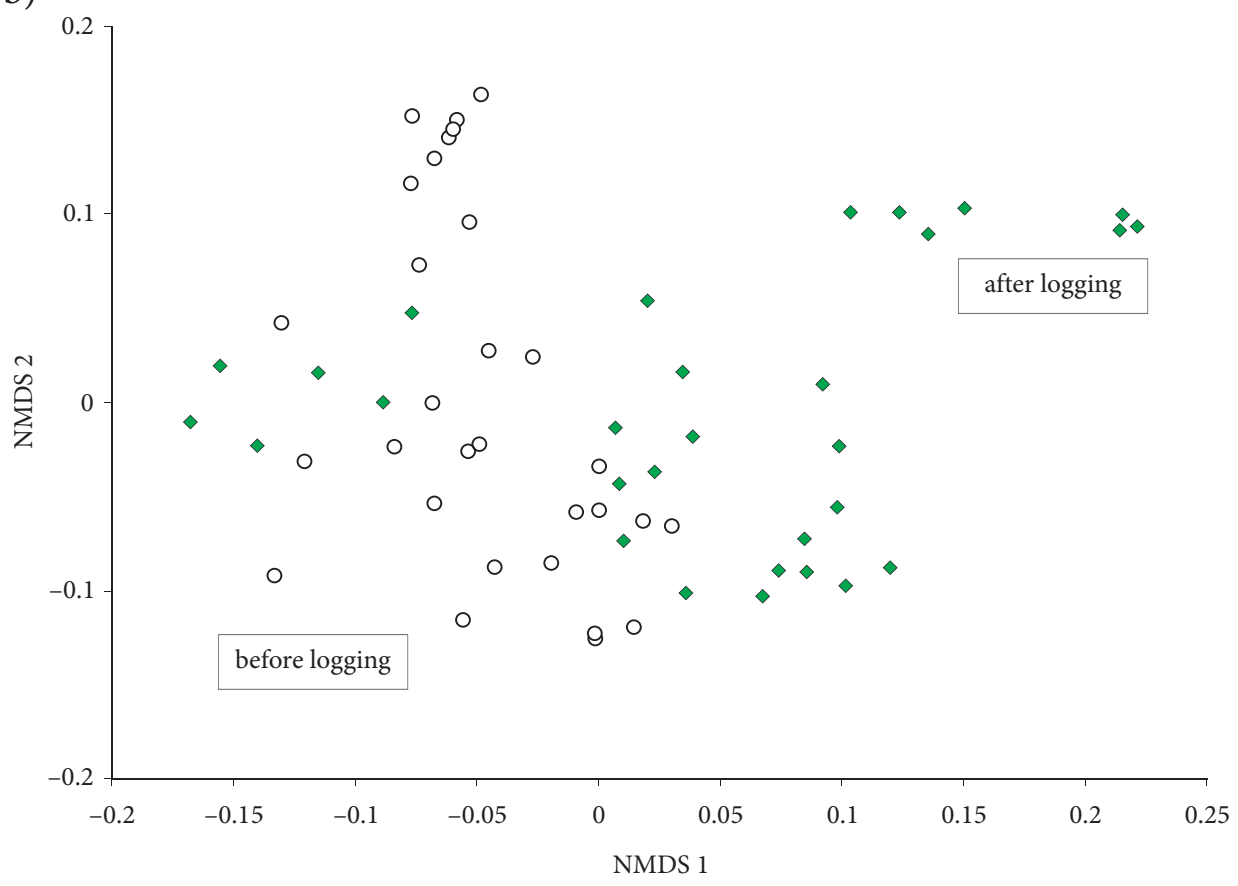

Figure 2: Non-metric multidimensional scaling (NMDS) ordination (cover values and Bray-Curtis index) diagrams of doline 1 (a) and doline 2 (b) before and after logging (stress factor: 0.24 and 0.22 , respectively). 

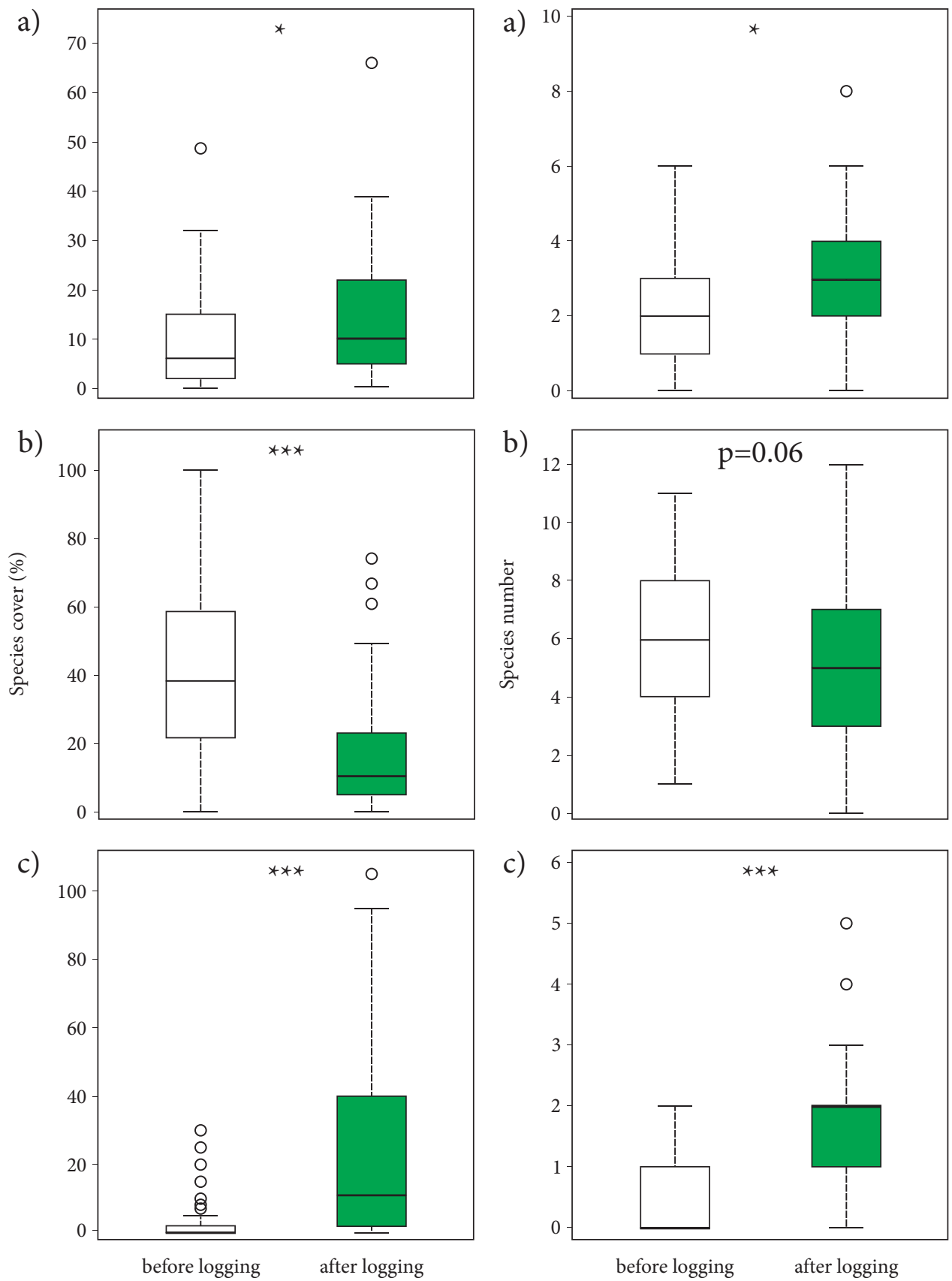

Management type

Figure 3: Cover and species number of the different functional groups (a: oak forest species; $b$ : beech and ravine forest species and c: disturbance-tolerant species) in the dolines of the Mecsek Mountains (Hungary) before (white boxes) and after (green boxes) logging. Significant differences are indicated by asterisks $\left({ }^{*} p<0.05 ;{ }^{* * *} p<0.001\right)$. 
(Bátori et al. 2011; 2014b), dolines in the Mecsek Mountains introduce great variation in species composition and many plant species can be found within them that are rare or totally absent from the surrounding karst plateaus (Bátori et al. 2012).

In general, changes in vegetation cover should affect the surface albedo (i.e. the amount of reflected solar radiation), wind pattern, soil hydrology, soil nutrient content, near-surface temperature and humidity, which in turn, should affect the vegetation (Saikh, Varadachari and Ghosh 1998; Guariguata and Ostertag 2001; Berbet and Costa 2003; Lukić et al. 2017; Stančič and Repe 2018). Our results show that intensive logging can cause significant changes in local species abundance and composition, and has a negative effect on the species-holding capacity of dolines (Figures 2 and 3). Dolines contained fewer beech and ravine forest species (e.g., narrow buckler-fern (Dryopteris carthusiana), herb Paris (Paris quadrifolia) and wood speedwell (Veronica montana) 10 years after logging, and their cover was much lower than before logging. In contrast, the number and cover of oak forest (e.g., field maple (Acer campestre), wood melick (Melica uniflora) and white violet (Viola alba)) and disturbance-tolerant species (e.g., wood small-reed (Calamagrostis epigejos), hairy blackberry (Rubus hirtus agg.) and stinging nettle (Urtica dioica)) increased significantly due to logging. The increase in the number and cover of oak forest species likely resulted from a decrease in albedo and a corresponding increase in absorbed solar radiation, while greater post-disturbance light and nutrient availability, changes in species interactions (such as competition) could increase the number and cover of disturbance-tolerant species. Since different species may recover at different rates during forest regeneration (Dunn 2004), it is unclear how species composition will change in these doline microrefugia in the future.

Extreme heat events are increasing in frequency in Central Europe, and will continue to do so throughout the next few decades (Bartholy et al. 2008). Climate warming affects the local abundance, phenology and distribution of species and alters the interactions between populations (Hegland et al. 2009). The distributions of many plant species in Europe are likely to shift upwards (Geßler et al. 2007; Czúcz, Gálhidy and Mátyás 2011; Hlásny et al. 2011), or species can persist in environmentally stable habitats (Willis, Rudner and Sümegi 2000; McLaughlin et al. 2017), such as dolines (Bátori et al. 2017). A number of studies indicate that forest cover has the potential to mitigate climate warming at local scales and to maintain suitable microclimate, enhancing species persistence (Frey et al. 2016; Keppel et al. 2017). The combined effects of forest cover and topographic complexity may contribute to the long-term persistence of forest species adapted to cooler conditions (beech and ravine forest species) (Figure 3) in the karst region of the Mecsek Mountains, provided that the current management intensity decreases. If this management practice continues, the species-holding capacity of these dolines would further decrease, and many currently widespread plant species may become rare or extinct during forest regeneration in a warming climate.

\section{Conclusion}

We conclude that intensive logging poses a serious threat on the species-holding capacity of karst depressions. To meet the demands of preservation of cool-adapted species in dolines, it would be necessary to establish more forest reserves on the karst surfaces where no forestry takes place. Alternatively, the maintenance of continuous forest cover in at least larger dolines and their surroundings would be indispensable to facilitate the recolonization or the in situ persistence of cool-adapted species under global warming.

ACKNOWLEDGEMENT: This research was founded by the NKFIH K 124796 grant. We are thankful to Izabella Benczur and Petra Vass for their help in field works.

\section{References}

Ashcroft, M. B. 2010: Identifying refugia from climate change. Journal of Biogeography 37-8. DOI: https://doi.org/10.1111/j.1365-2699.2010.02300.x

Bárány-Kevei, I. 1999: Microclimate of karstic dolines. Acta Climatologica Universitatis Szegediensis 32/33.

Bárány-Kevei, I. 2011: Changes in the vegetation of dolines in Aggtelek and Bükk Mountains. Acta Climatologica et Chorologica 44/45. 
Bartholy, J., Pongrácz, R., Gelybó, G., Szabó, P. 2008: Analysis of expected climate change in the Carpathian Basin using the PRUDENCE results. Időjárás 112, 3-4.

Bates, D., Maechler, M., Bolker, B. 2013: lme4: linear mixedeffects models using S4 classes. R package version 0.999999-2. Internet: http://cran.r-project.org/package=lme4 (26. 4. 2018).

Bátori, Z., Csiky, J., Erdős, L., Morschhauser, T., Török, P., Körmöczi, L. 2009: Vegetation of the dolines in Mecsek Mountains (South Hungary) in relation to the local plant communities. Acta Carsologica 38, 2-3. DOI: https://doi.org/10.3986/ac.v38i2-3.125

Bátori, Z., Csiky, J., Farkas, T., Vojtkó, E. A., Erdős, L., Kovács, D., Wirth, T., Körmöczi, L., Vojtkó, A. 2014a: The conservation value of karst dolines for vascular plants in woodland habitats of Hungary: refugia and climate change. International Journal of Speleology 43-1. DOI: https://doi.org/10.5038/1827-806X.43.1.2

Bátori, Z., Lengyel, A., Maróti, M., Körmöczi, L., Tölgyesi, C., Bíró, A., Tóth, M., Kincses, Z., Cseh, V., Erdős, L. 2014b: Microclimate-vegetation relationships in natural habitat islands: species preservation and conservation perspectives. Időjárás 118-3.

Bátori, Z., Gallé, R., Erdős, L., Körmöczi, L. 2011: Ecological conditions, flora and vegetation of a large doline in the Mecsek Mountains (South Hungary). Acta Botanica Croatica 70-2. DOI: https://doi.org/ 10.2478/v10184-010-0018-1

Bátori, Z., Körmöczi, L., Erdős, L., Zalatnai, M., Csiky, J. 2012: Importance of karst sinkholes in preserving relict, mountain, and wet-woodland plant species under sub-Mediterranean climate: A case study from southern Hungary. Journal of Cave and Karst Studies 74-1. DOI: https://doi.org/10.4311/ 2011LSC0216

Bátori, Z., Vojtkó, A., Farkas, T., Szabó, A., Havadtői, K., Vojtkó, E. A., Tölgyesi, C., Cseh, V., Erdős, L., Maák, I., Keppel G. 2017: Large- and small-scale environmental factors drive distributions of cooladapted plants in karstic microrefugia. Annals of Botany 119-2. DOI: https://doi.org/10.1093/aob/mcw233

Bátori, Z., Vojtkó, A., Maák, I. E., Lőrinczi, G., Farkas, T., Kántor, N., Tanács, E., Kiss, P. J., Juhász, O., Módra, G., Tölgyesi, C., Erdős, L., Aguilon, D. J., Keppel, G. 2019a: Karst dolines provide diverse microhabitats for different functional groups in multiple phyla. Scientific Reports 9. DOI: https://doi:10.1038/ s41598-019-43603-x

Bátori, Z., Vojtkó, A., Keppel, G., Tölgyesi, C., Čarni, A., Zorn, M., Farkas, T., Erdős, L., Kiss, P. J., Módra, G., Breg Valjavec, M. 2019b: Anthropogenic disturbances alter the conservation value of karst dolines. Biodiversity and Conservation. DOI: https://doi.org/10.1007/s10531-019-01896-4

Berbet, M. L. C., Costa, M. H. 2003: Climate change after tropical deforestation: seasonal variability of surface albedo and its effects on precipitation change. Journal of Climate 16. DOI: https://doi.org/10.1175/ 1520-0442(2003)016<2099:CCATDS>2.0.CO;2

Birks, H. H., Ammann, B. 2000: Two terrestrial records of rapid climatic change during the glacial-Holocene transition (14,000-9,000 calendar years B.P.) from Europe. PNAS 97-4. DOI: https://doi.org/10.1073/ pnas.97.4.1390

Breg Valjavec, M. 2014: Study of filled dolines by using 3D stereo image processing and electrical resistivity imaging. International Journal of Speleology 43-1. DOI: https://doi.org/10.5038/1827-806X.43.1.6

Breg Valjavec, M., Ribeiro, D., Čarni, A. 2017: Vegetation as the bioindicator of human-induced degradation in karst landscape: case study of waste-filled dolines. Acta Carsologica 46-1. DOI: https://doi.org/ 10.3986/ac.v46i1.4712

Breg Valjavec, M., Zorn, M., Čarni, A. 2018: Bioindication of human-induced soil degradation in enclosed karst depressions (dolines) using Ellenberg indicator values (Classical Karst, Slovenia). Science of the Total Environment 640/641. DOI: https://doi.org/10.1016/j.scitotenv.2018.05.294

Breg, M. 2007: Degradation of dolines on Logaško Polje (Slovenia). Acta Carsologica 36-2. DOI: https://doi.org/ 10.3986/ac.v36i2.191

Calò, F., Parise, M. 2006: Evaluating the human disturbance to karst environments in Southern Italy. Acta Carsologica 35, 2-3. DOI: https://doi.org/10.3986/ac.v35i2-3.227

Cernatič-Gregorič, A., Zega, M. 2010: The impact of human activities on dolines (Sinkholes) - typical geomorphologic features on karst (Slovenia) and possibilities of their preservation. Geographica Pannonica 14-4. DOI: https://doi.org/10.5937/GeoPan1004109C

Chytrý, M., Tichý, L., Holt, J., Botta-Dukát, Z. 2002: Determination of diagnostic species with statistical fidelity measures. Journal of Vegetation Science 13-1. DOI: https://doi.org/10.1111/j.1654-1103.2002.tb02025.x 
Czúcz, B., Gálhidy, L., Mátyás, C. 2011: Present and forecasted xeric climatic limits of beech and sessile oak distribution at low altitudes in Central Europe. Annals of Forest Science 68-1. DOI: https://doi.org/ 10.1007/s13595-011-0011-4

Dobrowski, S. Z. 2010: A climatic basis for microrefugia: the influence of terrain on climate. Global Change Biology 17-2. DOI: https://doi.org/10.1111/j.1365-2486.2010.02263.x

Dövényi, Z., Ambrózy, P., Juhász, Á., Marosi, S., Mezosi, G., Michalkó, G., Somogy, S., Szalai, Z., Tiner, T. 2010: Magyarország kistájainak katasztere (Inventory of microregions in Hungary). Budapest.

Dunn, R. R. 2004: Recovery of faunal communities during tropical regeneration. Conservation Biology 18-2. DOI: https://doi.org/10.1111/j.1523-1739.2004.00151.x

Egli, B. R. 1991: The special flora, ecological and edaphic conditions of dolines in the mountain of Crete. Botanika Chronika 10.

Frey, S. J. K., Hadley, A. S., Johnson, S. L., Schulze, M., Jones, J. A., Betts, M. G. 2016: Spatial models reveal the microclimatic buffering capacity of old-growth forests. Science Advances 2. DOI: https://doi.org/ 10.1126/sciadv. 1501392

Gentili, R., Baroni, C., Caccianiga, M., Armiraglio, S., Ghiani, A., Citterio, S. 2015: Potential warm-stage microrefugia for alpine plants: Feedback between geomorphological and biological processes. Ecological Complexity 21. DOI: https://doi.org/10.1016/j.ecocom.2014.11.006

Geßler, A., Keitel, C., Kreuzwieser, J., Matyssek, R., Seiler, W., Rennenberg, H. 2007: Potential risks for European beech (Fagus sylvatica L.) in a changing climate. Trees 21-1. DOI: https://doi.org/10.1007/ s00468-006-0107-x

Guariguata, M. R., Ostertag, R. 2001: Neotropical secondary forest succession: changes in structural and functional characteristics. Forest Ecology and Management 148, 1-3. DOI: https://oi.org/10.1016/S03781127(00)00535-1

Hegland, S. J., Nielsen, A., Lázaro, A., Bjerknes, A-L., Totland, Ø. 2009: How does climate warming affect plant-pollinator interactions? Ecology Letters 12-2. DOI: https://doi.org/10.1111/j.1461-0248.2008.01269.x

Hlásny, T., Barcza, Z., Fabrika M., Balázs, B., Churkina, G., Pajtík, J., Sedmák, R., Turčáni, M. 2011: Climate change impacts on growth and carbon balance of forests in Central Europe. Climate Research 47-3. DOI: https://doi.org/10.3354/cr01024

Horvat, I. 1953: Vegetacija ponikava. Geografski Glasnik 14/15.

Horváth, F., Dobolyi, Z. K., Morschhauser, T., Lőkös, L., Karas, L., Szerdahelyi, T. 1995: FLORA database. 1.2. Vácrátót.

Hoyk, E. 1999: Geoecological studies on the karstic surfaces of the planned protected area in Western Mecsek, South Hungary. Acta Carsologica 28-2. DOI: https://doi.org/10.3986/ac.v28i2.485

Iatroú, G., Fournaraki, C. 2006: Horstrissea dolinicola. The IUCN Red List of Threatened Species 2006. DOI: http://doi.org/10.2305/IUCN.UK.2006.RLTS.T61613A12522933.en

Kemencei, Z., Farkas, R., Páll-Gergely, B., Vilisics, F., Nagy, A., Hornung, E., Sólymos, P. 2014: Microhabitat associations of land snails in forested dolinas: implications for coarse filter conservation. Community Ecology 15-2. DOI: https://doi.org/10.1556/ComEc.15.2014.2.6

Keppel, G., Anderson, S., Williams, C., Kleindorfer, S., O'Connell, C. 2017: Microhabitats and canopy cover moderate high summer temperatures in a fragmented Mediterranean landscape. PLoS ONE 12-8. DOI: https://doi.org/10.1371/journal.pone.0183106

Keppel, G., Mokany, K., Wardell-Johnson, G. W., Phillips, B. L., Welbergen, J. A., Reside, A. E. 2015: The capacity of refugia for conservation planning under climate change. Frontiers in Ecology and the Environment 13-2. DOI: https://doi.org/10.1890/140055

Keppel, G., Van Niel, K. P., Wardell-Johnson, G. W., Yates, C. J., Byrne, M., Mucina, L., Schut, A. G. T., Hopper, S. D., Franklin, S. E. 2012: Refugia: identifying and understanding safe havens for biodiversity under climate change. Global Ecology and Biogeography 21-4. DOI: https://oi.org/10.1111/j.1466-8238.2011.00686.x

Kobal, M., Bertoncelj, I., Pirotti, F., Dakskobler, I., Kutnar, L. 2015: Using lidar data to analyse sinkhole characteristics relevant for understory vegetation under forest cover - case study of a high karst area in the Dinaric Mountains. PLoS ONE 10-3. DOI: https://doi.org/10.1371/journal.pone.0122070

Kovačičc, G., Ravbar, N. 2013: Analysis of human induced changes in a karst landscape - the filling of dolines in the Kras plateau, Slovenia. Science of the Total Environment 447. DOI: https://doi.org/10.1016/ j.scitotenv.2013.01.002

Lehmann, A. 1970: Tarvágás által okozott ökológiai változások az abaligeti karszton. Pécsi Müszaki Szemle 25. 
Lukić, T., Marić, P., Hrnjak, I., B. Gavrilov, M., Mladjan, D., Zorn, M., Komac, B., Milošević, Z., Marković, B. S., Sakulski, D., Jordaan, A., Đorđević, J., Pavić, D., Stojsavljević, R. 2017: Forest fire analysis and classification based on a Serbian case study. Acta geographica Slovenica 57-1. DOI: https://doi.org/ 10.3986/AGS.918

McLaughlin, B. C., Ackerly, D. D., Klos, P. Z., Natali, J., Dawson, T. E., Thompson, S. E. 2017: Hydrologic refugia, plants, and climate change. Global Change Biology 23-8. DOI: https://doi.org/10.1111/gcb.13629

Modrić Surina, Ž., Surina, B. 2010: Snowbed vegetation in Croatia: Phytosociology, ecology and conservation status. Plant Biosystems 144-4. DOI: https://doi.org/10.1080/11263504.2010.502716

Oksanen, J., Blanchet, F. G., Friendly, M., Kindt, R., Legendre, P., McGlinn, D., Minchin P. R., O’Hara, R. B., Simpson, G. L., Solymos, P., Stevens M. H. H., Szoecs, E., Wagner, H. 2018: Vegan: Community Ecology Package. Internet: http://CRAN.R-project.org/package=vegan (26.4.2018).

Pinheiro, J., Bates, D., DebRoy, S., Sarkar, D., and R Core Team 2018: nlme: linear and nonlinear mixed effects models. R package version 3.1-137. Internet: https://cran.r-project.org/web/packages/nlme/ index.html (26.4.2018).

R Core Team, 2018: R: A language and environment for statistical computing. Vienna. Internet: http://www.R-project.org/ (6.5.2018).

Raschmanová, N., Miklisová, D., Kováč, L., Šustr, V. 2015: Community composition and cold tolerance of soil Collembola in a collapse karst doline with strong microclimate inversion. Biologia 70-6. DOI: https://doi.org/10.1515/biolog-2015-0095

Ritter Beck von Mannagetta, G. 1906: Die Umkehrung der Pflanzenregionen in den Dolinen des Karstes. Deutsche Universität Prag, Prag.

Rull, V. 2009: Microrefugia. Journal of Biogeography 36-3. DOI: https://doi.org/10.1111/j.1365-2699.2008.02023.x

Růžička, V., Mlejnek, R., Juřičková, L., Tajovský, K., Šmilauer, P., Zajíček, P. 2016: Invertebrates of the Macocha Abyss (Moravian Karst, Czech Republic). Acta Carsologica 45-1. DOI: https://doi.org/10.3986/ac.v45i1.896

Saikh, H., Varadachari, C., Ghosh, K. 1998: Changes in carbon, nitrogen and phosphorus levels due to deforestation and cultivation: A case study in Simlipal National Park, India. Plant and Soil 198-2. DOI: https://doi.org/10.1023/A:1004391615003

Stančič, L., Repe, B. 2018: Post-fire succession: Selected examples from the Karst region, southwest Slovenia. Acta geographica Slovenica 58-1. DOI: https://doi.org/10.3986/AGS.1942

Stewart, J. R., Lister, A. M., Barnes, I. Dalén, L. 2010: Refugia revisited: individualistic responses of species in space and time. Proceedings of the Royal Society B 277-1682. DOI: https://doi.org/10.1098/rspb.2009.1272

Su, Y., Tang, Q., Mo, F., Xue, Y. 2017: Karst tiankengs as refugia for indigenous tree flora amidst a degraded landscape in southwestern China. Scientific Reports 7. DOI: https://doi.org/10.1038/s41598-017-04592-x

The plant list, 2018. Internet: http://www.theplantlist.org (6.5.2018).

Tichý, L. 2002: JUICE, software for vegetation classification. Journal of Vegetation Science 13-3. DOI: https://doi.org/10.1111/j.1654-1103.2002.tb02069.x

Troiani, N., Tardella, F. M., Malatesta, L., Corazza, M., Ferrari, C., Catorci, A. 2016: Long-term cropland abandonment does not lead per se to the recovery of semi-natural herb communities deemed habitats of community interest. Acta Botanica Croatica 75-2.

Whiteman, C. D., Haiden, T., Pospichal, B., Eisenbach, S., Steinacker, R. 2004: Minimum temperatures, diurnal temperature ranges, and temperature inversion in limestone sinkholes of different sizes and shapes. Journal of Applied Meteorology 43. DOI: https://doi.org/10.1175/1520-0450(2004)043<1224: MTDTRA $>2.0$. CO;2

Willis, K. J., Rudner, E., Sümegi, P. 2000: The full-glacial forests of Central and southeastern Europe. Quaternary Research 53-2. DOI: https://doi.org/10.1006/qres.1999.2119 